\title{
Efficacy of Nifedipine and Metoprolol in the Early Treatment of Unstable Angina in the Coronary Care Unit: Findings from the Holland Interuniversity Nifedipine/Metoprolol Trial (HINT)*
}

\author{
JACOBUS LUBSEN, MD, and JAN G.P. TIJSSEN, MSC, \\ for the HINT Research Group
}

A multicenter, double-blind, placebo-controlled, randomized trial of nifedipine, metoprolol and their combination was conducted in $\mathbf{3 3 8}$ patients with unstable angina (hospital admission diagnosis) who had not previously received treatment with a $\beta$ blocker. In addition, nlfedipine was compared with placebo in 177 patients who were receiving $\beta$ blockers upon hospital admission. The main outcome event was the recurrence of ischemia or progression to myocardial infarction within $\mathbf{4 8}$ hours. Trial medication effects are expressed as ratios of event rates relative to placebo, e.g., for nifedipine as the event rate under nifedipine divided by that under placebo; $95 \%$ confidence intervals are also given. In patients not pretreated with a $\beta$ blocker the rate ratio for nifedipine was $1.15(0.83,1.64)$, for metoprolol $0.76(0.49,1.16)$ and for the combi- nation $0.80(0.53,1.19)$. In patients already receiving a $\beta$ blocker, the addition of nifedipine was favorable and the rate ratio was $0.68(0.47,0.97)$.

Equal numbers of patients developed myocardial infarction and reversible ischemia. Most infarctions occurred early, within 6 hours of randomization. In patients who were not already taking a $\beta$ blocker, the nifedipine rate ratio for infarction only was 1.51 $(0.87,2.74)$. These results suggest that, in patients not previously receiving $\beta$ blockers, metoprolol has a beneficial short-term effect on unstable angina, that a fixed combination with nifedipine provides no further gain and that nifedipine may be ineffective or counterproductive. On the other hand, the addition of nifedipine to existing $\beta$ blockade when the patient becomes unstable seems beneficial.

(Am J Cardiol 1987;60:18A-25A)

1

atients referred to a coronary care unit for acute chest pain can be divided into 3 broad categories in terms of the clinical picture. They are:

1. neither the nature of the chest pain nor the admission electrocardiogram suggests a cardiac origin of the chest pain,

2. typical anginal pain at rest that is not severe enough to suggest acute myocardial infarction, combined with electrocardiographic evidence for myocardial ischemia but not for infarction and

From The Netherlands Interuniversity Cardiology Institute, Utrecht, The Netherlands. This study was supported in part by the Dutch Ministry of Education, and by grants from Bayer GmbH, Wuppertal, Germany, and Hassle AB, Molndal, Sweden.

Address for reprints: Jacobus Lubsen, MD, The Thoraxcenter, PO Box 1738, 3000 DR Rotterdam, The Netherlands.

${ }^{*}$ See Appendix for HINT participants.

3. severe anginal pain at rest combined with electrocardiographic evidence for evolving myocardial infarction.

Patients from the second category are often labelled as having "unstable angina". ${ }^{1}$ They are generally thought to be at high risk of progression to infarction. The objective of initial management is the restoration of a stable clinical condition, which allows further diagnostic work-up, including coronary angiography.

In controlling unstable angina in the coronary care unit, nitrates and $\beta$ blockade formed the cornerstone of conventional medical therapy until calcium antagonists became available. The latter are very effective against coronary spasm, and early experience suggested that they were effective in patients with unstable angina who do not respond to $\beta$ blockade and nitrates. ${ }^{2}$ The role of calcium antagonists and $\beta$ blockade, however, had not been well established at the time the Holland Interuniversity Nifedipine/metoprolol Trial (HINT) research group initiated a randomized, dou- 
ble-blind, placebo-controlled, multicenter trial in 1980. Its objective was to determine whether nifedipine [a calcium antagonist) and metoprolol [a $\beta$ blocker] could prevent recurrence of ischemia or progression to myocardial infarction when given either alone or in combination to patients diagnosed with unstable angina at admission to the coronary care unit. The trial was carried out under the auspices of the Interuniversity Cardiology Institute, in which all academic cardiology departments in the Netherlands participate.

The background, methods, results and conclusions from HINT have been extensively described elsewhere. ${ }^{3}$ We summarize herein the main findings in the 515 patients who were eventually available for analysis after the trial had been discontinued prematurely on October 30,1984, because an interim analysis suggestcd an increased risk for myocardial infarction in patients assigned to nifedipine who were not also receiving metoprolol.

\section{Patients and Methods}

Upon hospital admission, patients up to 70 years of age were screened for immediate inclusion without waiting for results of enzyme assessments. Patients suffering from chest pain after hospital admission qualified if the pain was anginal in nature, responded to nitroglycerin (maximum $2 \times 0.5 \mathrm{mg}$ sublingual or 1 $\mathrm{mg}$ in $10 \mathrm{ml} 5 \%$ glucose intravenously] or a small dose of fentanyl ( $0.05 \mathrm{mg})$, and was accompanied by a varying pattern of ST-T changes suggesting reversible myocardial ischemia. If chest pain had already subsided at hospital admission, a history of typical pain at rest or during light activity, lasting more than 15 minutes, combined with ST-T abnormalities or a documented history of coronary disease was required. Patients who did not qualify at hospital admission were included on the basis of the aforementioned criteria when chest pain subsequently developed, provided that available enzyme values were below twice the local upper limit for normal.

The following exclusion criteria were applied: more than 12 hours had elapsed since the last attack of pain, new Q-wave formation on the electrocardiogram, acute myocardial infarction within 1 week, maintenance treatment with nifedipine, heart rate below 50 or above 120 beats $/ \mathrm{min}$, systolic blood pressure below $100 \mathrm{~mm} \mathrm{Hg}$, systolic blood pressure above 170 $\mathrm{mm} \mathrm{Hg}$ and diastolic above $110 \mathrm{~mm} \mathrm{Hg}$, conduction abnormalities other than bundle branch block, anemia (hemoglobin <6.5 mmol/liter, if known), clinically overt heart failure, congenital or valvular heart disease, cardiomyopathy, serious pulmonary or other noncardiac disease or previous participation in this trial. After eligibility had been established, oral informed consent was requested and if it was obtained, trial medication was slurled without further delay.

All patients received routine care for at least 48 hours. Sedatives and anticoagulants were given according to local practice. Oral long-acting nitrates were continued if given before hospital admission; otherwise these drugs were not part of the standard regimen. Antiarrhythmics, digitalis, diuretics and anti- hypertensive agents other than $\beta$ blockers were given on indication only. Previous maintenance treatment with a $\beta$ blocker was continued; before November 13 , 1982 , with the same compound and dosage as given before, thereafter with $2 \times 100 \mathrm{mg}$ of metoprolol daily. Chest pain was treated initially as described previously. If pain persisted, further measures were left to the attending physician's discretion.

Trial medication was added to the standard regimen as follows. Patients not receiving previous maintenance treatment with a $\beta$ blocker for more than 3 days were randomly assigned to receive either double placebo, verum nifedipine $6 \times 10 \mathrm{mg}$ daily plus metoprolol placebo, verum metoprolol $2 \times 100 \mathrm{mg}$ daily plus nifedipine placebo or both drugs verum. Patients receiving previous maintenance treatment with a $\beta$ blocker were randomly assigned to receive placebo or nifcdipine $6 \times 10 \mathrm{mg}$ daily. No loading dosages were given. Both nifedipine and metoprolol (or their placebos] were started at the same time. Both randomizations were performed for each clinic separately and in equal proportions.

Unless persistent chest pain developed, the trial medication was continued for at least 48 hours, preferably until catheterization or discharge. In case of suspected side effects, trial medication was reduced or discontinued.

Before start of trial medication, a blood sample for cardiac enzyme assessments was obtained, and at least 1 electrocardiogram was recorded in the absence of pain. In patients who qualified after an in-hospital pain episode, at least 1 electrocardiogram during pain was also obtained. After start of trial medication, blood samples for cardiac enzyme assessment and electrocardiograms were obtained every 6 hours during a follow-up period of at least 54 hours. In addition, electrocardiograms were made during and after each attack of pain. Heart rate and blood pressure were recorded also at 6-hour intervals.

Based on these observations, the clinical outcome was classified as follows:

Prerandomization myocardial infarction was at least 1 cardiac enzyme level before the start of trial medication that was over 2 times the local upper limit for normal;

Myocardial infarction within 48 hours was a normal cardiac enzyme level at start of trial medication, followed by cardiac death or by a serial enzyme pattern characteristic for infarction with at least 1 enzyme value over twice the local upper limit for normal within 54 hours (enzymes up to that moment were taken into account in view of the intrinsic delay in enzyme release after the onset of infarction);

Recurrent ischemia within 48 hours was chest pain with ST changes combined with normal cardiac enzymes until 54 hours after the start of trial medication.

Myocardial infarction that occurred within the remainder of the first 7 days was recorded as diagnosed clinically. For all cases classified as myocardial infarction within 48 hours, the most likely time of onset was determined retrospectively from the complete clinical history. In addition, the time of appearance of a $Q$ wave exceeding 0.03 second in duration or of a $Q-$ 
wave equivalent $\left(\mathrm{R}>0.03\right.$ second in $\mathrm{V}_{1}$ and $\mathrm{R} / \mathrm{S}>1$ second in $\mathrm{V}_{2}$ ) was noted.

From the analysis, patients in whom an unequivocal protocol violation occurred before the start of trial medication were excluded. Treatment effects were assessed in terms of recurrent ischemia or myocardial infarction within 48 hours combined and in terms of myocardial infarction within 48 hours only. In accor-

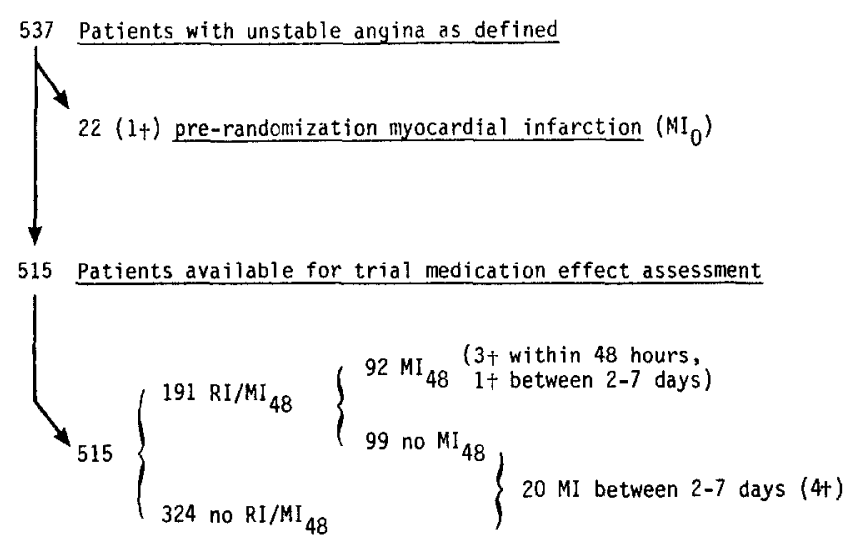

FIGURE 1. Patients excluded from data analysis and overall distributions of outcome events. $M t_{0}=$ prerandomization myocardial infarction; $\mathrm{MI}_{48}=$ myocardial infarction within 48 hours; $\mathrm{RI} / \mathrm{MI}_{48}=$ recurrent ischemia or myocardial infarction within 48 hours.

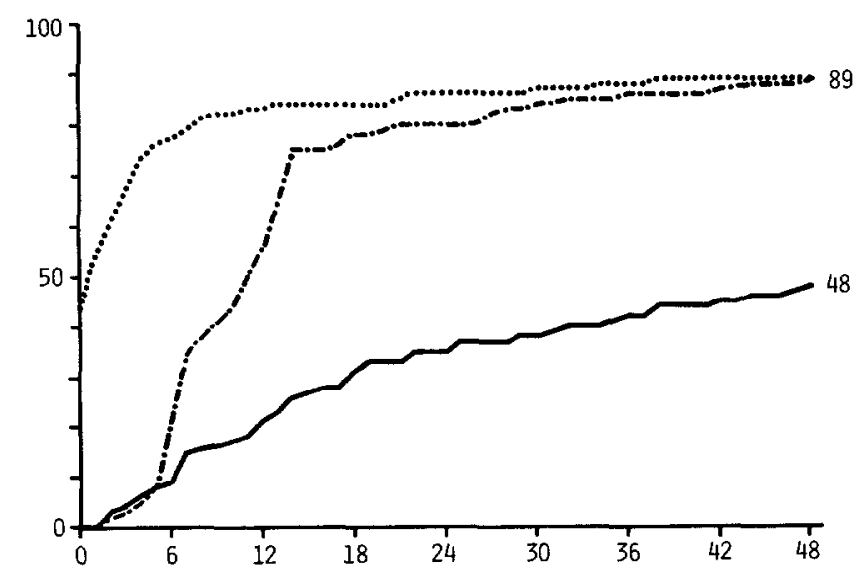

FIGURE 2. TIming of the onset of nonfatal myocardial infarction, the first significant increase in enzyme concentration and the appearance of $Q$ waves for 89 cases of nonfatal myocardlal infarction within 48 hours in 515 patients without enzymatic evidence of infarction at randomization. Time of the onset of myocardial infarction was determined retrospectively by the Classification Committee from the complete clinical history. The dotted line (top) represents the cumulative distribution of the time of onset of myocardial infarction; i.e., it represents for each point in time after randomization the total number of patients with an onset before that time. in $\mathbf{4 3}$ patients the onset was judged to have taken place before randomization; thus, this line starts at 43 . The middle line represents the cumulative distribution of the time of first increase in enzyme concentration to over twice the local upper limit of normal and the lower solid line the time of first appearance of a $Q$ wave on the electrocardiogram. The coordinate is the number of patients; the abscissa is time (hours). dance with the protocol, paticnts classificd as having had a prerandomization myocardial infarction were excluded from this assessment. Treatment effects were expressed as the ratio of the rate of the respective outcome event observed in patients allocated to a specific index trial medication to that observed in patients allocated to a specific reference trial medication. For instance, the effect of nifedipine relative to placebo is the rate of the outcome event in the nifedipine group divided by that in the placebo group. Thus, a unity rate ratio indicates that nifedipine has no effect relative to placebo. A rate ratio of less than unity points to a preventive effect, and a rate ratio greater than unity to a detrimental effect. In addition to the rate ratio estimates, their $95 \%$ confidence intervals are also given.

To determine which baseline characteristics were independently related to the risk for recurrent ischemia or myocardial infarction within 48 hours, a composite logistic prediction function was derived. Based on this function, the baseline risk for recurrent ischemia or myocardial infarction within 48 hours (i.e., the probability that this event would occur] was estimated for each patient separately given individual baseline characteristics and assuming allocation to placebo. Patients were subsequently divided in 3 subgroups of low, medium and high risk, respectively.

It was noted that trial treatment groups differed in terms of the distribution of baseline risk, despite random allocation. To adjust for this, relative treatment effects, as previously defined, were estimated as weighted averages of risk subgroup specific effects. Full details of the analytic methods used are given elsewhere. ${ }^{3}$

\section{Results}

Between February 1, 1981, and October 30, 1984, 668 patients were enrolled in 9 centers. A violation of the admission protocol occurred in 131 patients; thus, 537 patients had unstable angina as defined. As shown in Figure 1, another 22 patients were classified as having had a prerandomization myocardial infarction. These patients were left out from trial medication assessment. Figure 1 also shows the overall occurrence of relevant clinical events. All deaths were caused by myocardial infarction.

The time of onset in 89 patients with nonfatal myocardial infarction within 48 hours is shown in Figure 2. In 43 patients, acute myocardial infarction was thought to have occurred before the start of trial medication despite cardiac enzymes being below twice the upper limit for normal at that time. Figure 2 also displays the time of first occurrence of an increase in enzyme values over twice the upper limit for normal and that of a new $Q$ wave.

Selected baseline characteristics in relation to the defined outcome events are given in Table I. There were only small differences between the rates of recurrent ischemia or myocardial infarction within 48 hours for respective categories of age, sex, history of coronary disease and previous use of $\beta$ blockers.

Trial medication was started after a pain-free interval of less than 1 hour in $26 \%$ of patients and in a 
further $36 \%$ after an interval between 1 and 3 hours. The length of this interval was strongly related to the rate of recurrent ischemia or myocardial infarction within 48 hours: of patients who had a pain-free interval of less than 1 hour, $62 \%$ developed recurrent ischemia or myocardial infarction within 48 hours as opposed to $22 \%$ of those with a pain-free interval greater than 3 hours (Table I). The rate of recurrent ischemia or myocardial infarction within 48 hours was also related to the presence of ST depressions greater than 0.1 $\mathrm{mV}$ on the baseline electrocardiogram. Patients without pain observed while in hospital had a lower event rate than those with pain. In those patients with pain the event rate was also related to the presence of changes in ST coding during pain.

Of the baseline characteristics listed in Table I, previous use of $\beta$ blockers, pain-free interval before starting and ST coding of electrocardiograms made during and after pain were retained in the logistic function for the estimation of the baseline risk for recurrent ischemia or myocardial infarction within 48 hours. Based on this estimation, $59 \%$ of patients were grouped as "low," $24 \%$ as "medium" and $17 \%$ as "high" risk. The observed rates were $21 \%, 53 \%$ and $69 \%$, respectively. The rate of myocardial infarction within 48 hours was also strongly related to this stratification. Full details of the logistic function are given elsewhere. ${ }^{3}$

Baseline risk for recurrent ischemia or myocardial infarction within 48 hours was distributed differently over the trial medication groups: among patients not receiving previous maintenance treatment with a $\beta$ blocker, $18 \%$ of those allocated to nifedipine were "high" risk; for the other 3 trial medication groups this percentage ranged from $5 \%$ to $12 \%$. The higher risk of the nifedipine group was due primarily to a relatively large proportion $(33 \%$ ) of patients in whom trial medication was started within 1 hour after the last attack of pain (a strong indicator of risk, Table I). In patients who received continued $\beta$ blockade the same was true for patients allocated to placebo, although to a lesser extent.

At 48 hours, the percentage of patients still receiving trial medication ranged from $63 \%$ of patients allocated to nifedipine who had not received previous maintenance $\beta$ blockade to $76 \%$ of patients allocated to placebo in the same category of previous $\beta$ blockade. The predominant reasons for discontinuation were recurrent chest pain and diagnostic findings of myocardial infarction.

Regarding concomitant medication, oral long-acting nitrates had been given to 100 patients at hospital admission and were continued in $76 \%$. Thus, 439 patients did not receive oral long-acting nitrates at randomization. These drugs were later prescribed, on indication, in $11 \%$ of these patients. Anticoagulants (coumarin or heparin) were given to $67 \%$. At start or during follow-up $14 \%$ received diuretics, $3 \%$ digitalis and $3 \%$ platelet aggregation-inhibiting drugs.

Trial medication allocation and clinical events are shown in Table II both overall and, except for prerandomization infarction, per stratum of baseline risk for recurrent ischemia or myocardial infarction within 48
TABLE I Baseline Characteristics and Corresponding Outcome Event Rates

\begin{tabular}{|c|c|c|c|}
\hline All Patients & $(515=100 \%)$ & $\begin{array}{c}\mathrm{RI} / \mathrm{MI}_{48} \\
191(37 \%)\end{array}$ & $\begin{array}{c}\mathrm{Ml}_{48} \\
92(18 \%)\end{array}$ \\
\hline \multicolumn{4}{|l|}{ Age (years) } \\
\hline$<55$ & $(183=36 \%)$ & $69(38 \%)$ & $38(21 \%)$ \\
\hline $55-65$ & $(248=48 \%)$ & $92(37 \%)$ & $40(16 \%)$ \\
\hline$>65$ & $(84=16 \%)$ & $30(36 \%)$ & $14(17 \%)$ \\
\hline \multicolumn{4}{|l|}{ Sex } \\
\hline Male & $(387=75 \%)$ & $149(39 \%)$ & $82(21 \%)$ \\
\hline Female & $(128=25 \%)$ & $42(33 \%)$ & $10(8 \%)$ \\
\hline \multicolumn{4}{|l|}{ History of MI } \\
\hline no & $(340=66 \%)$ & $134(39 \%)$ & $68(20 \%)$ \\
\hline yes & $(175=34 \%)$ & $57(33 \%)$ & $24(14 \%)$ \\
\hline \multicolumn{4}{|l|}{$\begin{array}{l}\text { History of angina } \\
>4 \text { weeks }\end{array}$} \\
\hline no & $(308=60 \%)$ & $116(38 \%)$ & $61(20 \%)$ \\
\hline yes & $(207=40 \%)$ & $75(36 \%)$ & $31(15 \%)$ \\
\hline \multicolumn{4}{|c|}{$\begin{array}{l}\text { Previous maintenance } \\
\text { treatment with a } \\
\beta \text { blocker }\end{array}$} \\
\hline no & $(338=66 \%)$ & $121(36 \%)$ & $63(19 \%)$ \\
\hline yes & $(177=34 \%)$ & $70(40 \%)$ & $29(16 \%)$ \\
\hline \multicolumn{4}{|c|}{ Pain-free interval (hours) } \\
\hline$<1$ & $(133=26 \%)$ & $82(62 \%)$ & $45(34 \%)$ \\
\hline $1-3$ & $(186=36 \%)$ & $66(35 \%)$ & $31(17 \%)$ \\
\hline$>3$ & $(196=38 \%)$ & $43(22 \%)$ & $16(8 \%)$ \\
\hline \multicolumn{4}{|l|}{ Baseline ECG } \\
\hline not codable & $(20=4 \%)$ & $8(40 \%)$ & $6(30 \%)$ \\
\hline no $S T \downarrow \geq 0.1 \mathrm{mV}$ & $(402=78 \%)$ & $136(34 \%)$ & $60(15 \%)$ \\
\hline $\mathrm{ST} \downarrow \geq 0.1 \mathrm{mV}$ & $(93=18 \%)$ & $47(51 \%)$ & $26(28 \%)$ \\
\hline \multicolumn{4}{|c|}{$\begin{array}{c}\text { Comparison of pain ECG } \\
\text { with baseline ECG }\end{array}$} \\
\hline not possible* & $(223=43 \%)$ & $48(22 \%)$ & $24(11 \%)$ \\
\hline same ST coding & $(82=16 \%)$ & $32(39 \%)$ & $11(13 \%)$ \\
\hline more $S T \downarrow \dagger$ & $(159=31 \%)$ & $87(55 \%)$ & $45(28 \%)$ \\
\hline more ST $\uparrow^{\dagger}$ & $(101=20 \%)$ & $60(59 \%)$ & $32(32 \%)$ \\
\hline \multicolumn{4}{|c|}{ Baseline risk for $\mathrm{RI} / \mathrm{MI}_{48}{ }^{\ddagger}$} \\
\hline low & $(303=59 \%)$ & $65(21 \%)$ & $28(9 \%)$ \\
\hline medium & $(126=24 \%)$ & $67(53 \%)$ & $28(22 \%)$ \\
\hline high & $(86=17 \%)$ & $59(69 \%)$ & $36(42 \%)$ \\
\hline
\end{tabular}

$E C G=$ electrocardiogram; $\mathrm{Ml}_{48}=$ myocardial infarction within 48 hours; $\mathrm{RI} / \mathrm{Ml}_{48}=$ recurrent ischemia or myocardial infarction within 48 hours; ST $\downarrow=$ ST-segment depression.

* No pain observed after hospital admission or no (codable) pain-free electrocardiogram available for comparison.

${ }^{\dagger}$ Including $\mathbf{5 0}$ patients who had more ST depression as well as more ST elevation.

$\ddagger$ As estimated from previous maintenance treatment with a $\beta$ blocker, painfree interval and electrocardiographic variables.

hours. The directions of the differences between the trial medication groups were consistent over the risk strata. In patients not receiving previous maintenance treatment with a $\beta$ blocker who were treated with nifedipine, both outcome event rates were higher than the corresponding rates for those receiving placebo. This was also true for Q-wave infarctions. On the other hand, in patients given metoprolol or the combination, outcome event rates tended to be lower than the rates for those given placebo. In patients who were already receiving a $\beta$ blocker, the nifedipine group tended to have lower outcome event rates than the placebo group.

For all choices of index and reference trial medication the estimated relative effects expressed as weightcd averages of risk stratum specific rate ratios are giv- 
TABLE II Outcome Event Rates in Trial Medication Groups Stratified for Estimated Baseline Risk for Recurrent Ischemia or Myocardial Infarction Within $\mathbf{4 8}$ Hours

\begin{tabular}{|c|c|c|c|c|c|}
\hline & $\mathbf{M I}_{0}$ & no $\mathrm{Ml}_{0}$ & $\mathrm{RI} / \mathrm{Ml}_{48}$ & $\mathrm{ML}_{48}$ & $\mathrm{MI}_{48}+\mathrm{Q}$ \\
\hline \multicolumn{6}{|c|}{$\begin{array}{l}\text { No previous maintenance } \\
\text { treatment with a } \\
\beta \text { blocker }\end{array}$} \\
\hline \multicolumn{6}{|l|}{ Placebo } \\
\hline all patients & 3 & 84 & $31(37 \%)$ & $13(15 \%)$ & $9(11 \%)$ \\
\hline low risk & & 56 & $13(23 \%)$ & $3(5 \%)$ & $2(4 \%)$ \\
\hline medium risk & & 22 & $13(59 \%)$ & $8(36 \%)$ & $6(27 \%)$ \\
\hline high risk & & 6 & $5(83 \%)$ & $2(33 \%)$ & $1(17 \%)$ \\
\hline \multicolumn{6}{|l|}{ Nifedipine } \\
\hline all patients & 4 & 89 & $42(47 \%)$ & $25(28 \%)$ & $14(16 \%)$ \\
\hline low rlsk & & 53 & $15(28 \%)$ & $8(15 \%)$ & $4(8 \%)$ \\
\hline medium risk & & 20 & $14(70 \%)$ & $6(30 \%)$ & $4(20 \%)$ \\
\hline high risk & & 16 & $13(81 \%)$ & $11(69 \%)$ & $6(38 \%)$ \\
\hline \multicolumn{6}{|l|}{ Metoprolol } \\
\hline all patients & 4 & 79 & $22(28 \%)$ & $13(16 \%)$ & $6(8 \%)$ \\
\hline low risk & & 52 & $10(19 \%)$ & $6(12 \%)$ & $2(4 \%)$ \\
\hline medium risk & & 23 & $9(39 \%)$ & $5(22 \%)$ & $3(13 \%)$ \\
\hline high risk & & 4 & $3(75 \%)$ & $2(50 \%)$ & $1(25 \%)$ \\
\hline \multicolumn{6}{|l|}{ Combination } \\
\hline all patients & 7 & 86 & $26(30 \%)$ & $12(14 \%)$ & $7(8 \%)$ \\
\hline low risk & & 56 & $9(16 \%)$ & $4(7 \%)$ & $3(5 \%)$ \\
\hline medium risk & & 20 & $12(60 \%)$ & $5(25 \%)$ & $2(10 \%)$ \\
\hline high risk & & 10 & $5(50 \%)$ & $3(30 \%)$ & $2(20 \%)$ \\
\hline \multicolumn{6}{|c|}{$\begin{array}{l}\text { Continued maintenance } \\
\text { treatment with a } \\
\beta \text { blocker }\end{array}$} \\
\hline \multicolumn{6}{|c|}{ Placebo } \\
\hline all patients & 2 & 81 & $41(51 \%)$ & $16(20 \%)$ & $6(7 \%)$ \\
\hline low risk & & 34 & $8(24 \%)$ & $3(9 \%)$ & $2(6 \%)$ \\
\hline medium risk & & 18 & $12(67 \%)$ & $2(11 \%)$ & $0(0 \%)$ \\
\hline high risk & & 29 & $21(72 \%)$ & $11(38 \%)$ & $4(14 \%)$ \\
\hline \multicolumn{6}{|l|}{ Nifedipine } \\
\hline all patients & 2 & 96 & $29(30 \%)$ & $13(14 \%)$ & $6(6 \%)$ \\
\hline low risk & & 52 & $10(19 \%)$ & $4(8 \%)$ & $0(0 \%)$ \\
\hline medium risk & & 23 & $7(30 \%)$ & $2(9 \%)$ & $2(9 \%)$ \\
\hline high risk & & 21 & $12(57 \%)$ & $7(33 \%)$ & $4(19 \%)$ \\
\hline
\end{tabular}

TABLE III Rate Ratios with $95 \%$ Confidence Intervals for All Pairwise Trial Medications Comparisons

\begin{tabular}{|c|c|c|}
\hline & \multicolumn{2}{|c|}{$\begin{array}{c}\text { Adjusted Rate Ratio } \\
\text { (95\% confidence interval) }\end{array}$} \\
\hline & $\mathrm{RI} / \mathrm{MI}_{48}$ & $\mathrm{MI}_{48}$ \\
\hline \multicolumn{3}{|c|}{$\begin{array}{l}\text { No previous maintenance } \\
\text { treatment with a } \\
\beta \text { blocker }\end{array}$} \\
\hline $\begin{array}{l}\text { Nifedipine/ } \\
\text { Placebo }\end{array}$ & $\begin{array}{c}1.15 \\
(0.83,1.64)\end{array}$ & $\begin{array}{c}1.51 \\
(0.87,2.74)\end{array}$ \\
\hline $\begin{array}{l}\text { Metoprolol/ } \\
\text { Placebo }\end{array}$ & $\begin{array}{c}0.76 \\
(0.49,1.16)\end{array}$ & $\begin{array}{c}1.07 \\
(0.54,2.09)\end{array}$ \\
\hline $\begin{array}{l}\text { Combination/ } \\
\text { Placebo }\end{array}$ & $\begin{array}{c}0.80 \\
(0.53 .1 .19)\end{array}$ & $\begin{array}{c}0.88 \\
(0.44 .1 .74)\end{array}$ \\
\hline $\begin{array}{l}\text { Metoprolal/ } \\
\text { Nifedipine }\end{array}$ & $\begin{array}{c}0.66 \\
(0.43,0.98)\end{array}$ & $\begin{array}{c}0.74 \\
(0.40,1.31)\end{array}$ \\
\hline $\begin{array}{c}\text { Combination/ } \\
\text { Nifedipine }\end{array}$ & $\begin{array}{c}0.68 \\
(0.47,0.97)\end{array}$ & $\begin{array}{c}0.56 \\
(0.30,0.99)\end{array}$ \\
\hline $\begin{array}{r}\text { Combination/ } \\
\text { Metoprolol }\end{array}$ & $\begin{array}{c}1.06 \\
(0.67,1.70)\end{array}$ & $\begin{array}{c}0.79 \\
(0.39,1.62)\end{array}$ \\
\hline \multicolumn{3}{|c|}{$\begin{array}{l}\text { Continued maintenance } \\
\text { treatment with a } \\
\beta \text { blocker }\end{array}$} \\
\hline $\begin{array}{l}\text { Nifedipine/ } \\
\text { Placebo }\end{array}$ & $\begin{array}{c}0.68 \\
(0.47,0.97)\end{array}$ & $\begin{array}{c}0.86 \\
(0.45,1.61)\end{array}$ \\
\hline
\end{tabular}

Abbreviations as in Table I. en in Table III together with their $95 \%$ confidence intervals.

\section{Discussion}

Our results confirm earlier reports that myocardial infarction is a frequent complication in patients admitted to hospital with unstable angina. ${ }^{1}$ After 1 week it had occurred in $25 \%(22+92+30$ out of 537, Fig. 1). But the exact timing of the early complications relative to the moment of diagnosis was not reported earlier. Inclusion in this trial was based on a diagnosis of unstable angina made at hospital admission by a conventional clinical assessment of the nature of the symptoms and signs but withuut waiting for the enzyme assessment results to be returned from the laboratory. Notwithstanding the diagnosis of unstable angina, myocardial infarction with enzyme increases had already taken place in $4 \%$ (22 of 537 , Fig. 1). Further, as is shown in Figure 2, 43 of 515 patients with normal enzymes at the moment of diagnosis (i.e., start of trial medication) had infarction already occurring, although it could not be recognized at that moment.

These results show that it is impossible to delineate reversible ischemia (i.e., unstable angina) reliably from irreversible ischemia (i.e., myocardial infarction) 
early on clinical grounds. It follows that the possible presence of myocardial infarction must be taken into account in the initial management of unstable angina and that, inasmuch as infarction has already occurred, limitation of its size is one of the management objectives.

Another objective of the initial management of unstable angina must be the prevention of progression to myocardial infarction. Of 515 patients with normal enzymes at the moment of diagnosis (Table I], nonfatal infarction with an onset after that moment but within 48 hours occurred in only 39 (89 to 43 , Fig. 2) patients while there were a further 3 fatal cases of infarction within that period of time. Most of these infarcts had an onset within 6 hours (Fig. 2). The clinical implication of these findings is that there are relatively few infarcts that can really be prevented and that there is very little time to take the necessary measures.

Despite the high incidence of myocardial infarction, this trial supports the notion that the prognosis for patients with this type of unstable angina is relatively good. Total 1 -week mortality was only $1.7 \%$ (9/537, Fig. 1). Our results indicate that the short-term risk for recurrent ischemia or myocardial infarction is primarily relaterl to the time elapsed since the last attack of pain on the one hand and to the presence of resting ST abnormalities and pain-related ST changes on the other [Table I]. The first finding is understandable because by definition the condition of patients with a long interval between last pain attack and diagnosis has stabilized. The second finding is in agreement with current views and previous findings on the relevance of electrocardiography in such patients. ${ }^{1,4}$

Enrollment in the present trial was discontinued on the basis of an interim analysis. ${ }^{3}$ The final data as presented herein are essentially in agreement with the interim data that led to this decision.

Although the total series of patients is of considerable size, each separate trial medication group is rather small. In a randomized trial with small groups, the possibility that the eventual data suggest differences in baseline risk between the groups should be taken into account. Since this did indeed occur, we have used risk stratification on the basis of a composite logistic function of relevant baseline characteristics, and have expressed trial medication effects as weighted averages of stratum specific rate ratios. By this approach, the estimation of trial medication effect becomes independent of the actual distribution of baseline risk in the groups that are compared. Of the rate ratios so obtained, $95 \%$ confidence intervals are presented, as these provide better insight in the statistical strength of evidence than the customary significance levels ( $p$ values). ${ }^{5}$

Patients with a prerandomization myocardial infarction are no longer "at risk" of the defined outcome events. Therefore, we have assessed trial medication effects without taking these patients into consideration. To allow effect analyses based on other principles, the number of prerandomization infarctions is also given per treatment group (Table II).

Only the addition of nifedipine to previous maintenance treatment with a $\beta$ blocker turned out to be clearly beneficial. None of the other trial regimens came out unequivocally effective. There was a trend for metoprolol to reduce the risk of recurrent ischemia or myocardial infarction but there was a worrying trend towards an increased risk for myocardial infarction in patients assigned to nifedipine alone. What is the explanation for these findings?

Regarding the preventive effect of nifedipine in patients already taking a $\beta$ blocker, we hypothesize that in patients who become unstable despite such maintenance treatment, coronary spasm may play a larger role than in patients not receiving previous $\beta$ blockade, thereby explaining the efficacy of adding a coronary spasmolytic agent such as nifedipine.

Regarding the apparent lack of major effects of the other trial medications, we do not believe that it is due to the selection of already stabilized patients, which would lead to a lack of sufficient outcome events. The event rate of recurrent ischemia or myocardial infarction within 48 hours was considerable and in agreement with a priori design assumptions. Nevertheless, the possibility that relevant trial medication effects were "missed" cannot be dismissed outright on the basis of the confidence intervals given in Table III. In our view, the most likely explanation lies in the particular clinical situation with which this trial was concerned, which allows limited scope for prevention. In this context, it is noted that nifedipine has not been shown to reduce infarct size or mortality when given to patients with myocardial infarction. ${ }^{6,7}$ Animal experiments indicate that nifedipine has no protective effect on the myocardium when given after onset of ischemia. $^{8}$

Why nifedipine monotherapy should actually increase the risk for progression to myocardial infarction cannot be determined from our data. There is the possibility that this is a chance finding. On the other hand, these findings virtually exclude a major preventive effect of nifedipine used in this way for this indication. We do not believe that nifedipine's postulated influence on release of enzymes ${ }^{9}$ could explain this finding: There was also an excess in Q-wave infarcts in the nifedipine monotherapy group compared with placebo (Table II). In comparison with placebo, nifedipine did not increase heart rate substantially but did lower blood pressure. It is possible therefore that the temporary increase in heart rate in combination with a decrease in blood pressure, which has been observed before, ${ }^{10}$ plays a role.

Nifedipine is generally accepted to be of particular value in patients with ST elevation during pain. There was a total of 101 patients in whom this was documented before entry (Table I). A subgroup analysis did not reveal that these patients benefited particularly from nifedipine monotherapy.

The HINT findings do not stand alone but fit a pattern of earlier studies. In a trial with a selection procedure beginning immediately at hospital admission, $4 \times 20 \mathrm{mg}$ of nifedipine daily was compared with placebo. ${ }^{11}$ However, eligibility required more prolonged chest pain than in the present trial and patients with electrocardiographic evidence of acute infarction were not excluded. Patients were later stratified into 
either acute or threatened myocardial infarction on the basis of the presence or absence of enzyme increases and $Q$ waves at the moment of randomization. Their threatened myocardial infarction group resembled the group of patients included in the present trial. Most likely as a reflection of the more stringent selection as far as pain is concerned, the rate of progression to myocardial infarction, $75 \%$ after 24 hours, was much higher however. The progression rate did not differ between the nifedipine and placebo group, nor was there a difference in enzymatic infarct size. The actual number of patients also treated with a $\beta$ blocker was not reported, rendering a direct comparison with our results impossible. Another trial ${ }^{12}$ in patients diagnosed as having "threatened infarction" compared propranolol with conventional treatment. The effect of propranolol was in the same direction as that of metoprolol in the present trial.

Several trials have studied treatments in patients with unstable angina after enzyme levels were known to be normal, albeit with varying selection criteria. One observed a favorable effect of the addition of nifedipine to a standard regimen of propranolol and long-acting nitrates on recurrent ischemia over a follow-up period of 3 months. ${ }^{13}$ Nifedipine without concomitant $\beta$ blockade was not studied. Another trial ${ }^{14}$ compared a conventional step-up regimen of long-acting nitrates and propranolol with increasing dosages of nifedipine during a treatment period of 14 days. Overall, there were no differences in recurrent ischemia, and $14 \%$ of patients progressed to infarction in both groups. Because this trial did not have a placebo control group, it is not possible to tell whether both regimens were equally effective or equally ineffective. In the subgroup of patients who were receiving maintenance treatment with propranolol the addition of nifedipine controlled pain more rapidly than did the addition of nitrates or an increase in propranolol dosage. On the other hand, in the subgroup of patients who were not receiving maintenance propranolol the administration of this drug or nitrates controlled pain more rapidly than did nifedipine. Our results are in agreement with these findings. Moreover, they provide evidence for a positive effect of a particular $\beta$ blocker in patients not already receiving such treatment compared with placebo, and for a similar effect of nifedipine in patients already receiving treatment with a $\beta$ blocker.

In summary, the present results confirm that, with currently available diagnostic methods, it is impossible to reliably delineate unstable angina from evolving myocardial infarction at admission to a coronary care unit. Of patients suspected of unstable angina, a considerable proportion in fact has already sustained a myocardial infarction or is in the process of doing so. Initial management must take into account the possible presence of evolving myocardial infarction. The first management objective therefore becomes the reduction of the total number of infarcts eventually diag- nosed among this subgroup of patients, irrespective of the precise time of onset relative to the initiation of therapy. To achieve this, therapy must both reduce the size of evolving infarctions and prevent those about to develop.

Regarding therapy, our results indicate that previous $\beta$ blockade is an important consideration. In patients not receiving previous $\beta$ blockade, they support the use of a $\beta$ blocker as first choice treatment. There was no additional advantage of the fixed combination of metoprolol and nifedipine. Patients with ST elevations during pain did not seem to benefit particularly from nifedipine. Further, nifedipine cannot be recommended as monotherapy because it was associated with a higher incidence of myocardial infarction. On the other hand, patients who have become unstable despite maintenance treatment with a $\beta$ blocker can be expected to react favorably to the addition of nifedipine to a regimen of continued $\beta$ blockade.

\section{References}

1. Nattel S, Warnica JW, Ogilvie RI. Indications for admission to a coronary care unit in patients with unstable angina. Can Med Assoc J 1980;122:180-184. 2. Hugenholtz PG, Michels HR, Serruys PW, Brower RW. Nifedipine in the treatment of unstable angina, coronary spasm and myocardial ischemia. Am J Cardiol 1981:47:163-173.

3. The Holland Interuniversity Nifedipine/metoprolol Trial (HINT) Research Group. Early treatment of unstable angina in the coronary care unit: a randomised, double blind, placebo controlled comparison of recurrent ischaemia in patients treated with nifedipine or metoprolol or both. $\mathrm{Br}$ Heart J 1986;56:400-413.

4. Yusuf S, Pearson M, Sterry H, Parish S, Ramsdale D, Rossi P, Sleight P. The entry ECG in the early diagnosis and prognostic stratification of patients with suspected acute myocardial infarction, Eur Heart / 1984;5:690 -696.

5. Pocock SJ. Current issues in the design and interpretation of clinical trials. Br Med J 1985;290:39-42.

6. Sirnes PA, Overskeid K, Pedersen TR, Bathen J, Drivenes A, Froland GS, Kjekshus JK, Landmark K, Rokseth R, Sirnes KE, Sundoy A, Torjussen BR, Westlund KM, Wik BA. Evolution of infarct size during the early use of nifedipine in patients with acute myocardial infarction: the Norwegian nifedipine multicenter trial. Circulation 1984;70:638-644.

7. Wilcox RG, Hamptom IR, Banks DC, Birkhead JS, Brooksby IAB, BurnsCox CJ, Hayes MI, Joy MD, Malcolm AD, Mather HG, Rowley JM. Trial of early nifedipine in acute myocardial infarction: the TRENT study. Br Med I 1986;293:1204-1208.

8. Nayler WG, Sturrock W], Dillon IS. Reperfusion of the ischaemic myocardium: do the $\mathrm{Ca}^{2+}$-antagonists help? In: Hugenholtz PG, Goldman BS, eds. Unstable Angina. Current Concepts and Management. Stuttgart-New York: Schattauer, 1985:187-197.

9. Loogna E, Sylven G, Groth T, Mogensen L. Complexity of enzymo release during acute myocardial infarction in a controlled study with early nifedipine treatment. Eur Heart I 1985;6:114-119.

10. Boden WE, Korr KS, Bough EW. Nifedipine-induced hypotension and myocardial ischemia in refractory angina pectoris. JAMA 1985;253:113111,35 .

11. Muller JE, Morrison ], Stone PH, Rude RE, Rosner B, Roberts R, Pearle DL, Turi ZG, Schneider JF, Serfas DH, Tate C, Scheiner E, Sobel BE, Hennekens CH, Braunwald E. Nifedipine therapy for patients with threatened and acute myocardial infarction: a randomized, double-blind, placebo-controlled comparison. Circulation 1984;69:740-747.

12. Norris RM, Clarke ED, Sammel NL, Smith WH, Williams B. Protective effect of propranolol in threatened myocardial infarction. Lancet 1978;2:907o09.

13. Gerstenblith G, Ouyang P, Achuff SC, Bulkley BH, Becker LC, Mellits ED, Baughman KL, Weiss JL, Flaherty JT, Kallman CH, Llewellyn M, Weisfeld MI.. Nifedipine in unstable angina. A double-blind randomized trial. N Engl J Med 1982;306:885-889.

14. Muller IE, Turi ZG, Pearle DL, Schneider JF, Serfas DH, Morrison D, Stone PH, Rude RE, Rosner B, Sobel BE, Tate C, Scheiner E, Roberts R, Hennekens $\mathrm{CH}$, Braunwald E. Nifedipine and conventional therapy for unstable angina pectoris: a randomized, double-blind comparison. Circulation 1984;69:728-739. 


\begin{tabular}{|c|c|c|c|}
\hline \multirow[t]{4}{*}{ Executive Committee } & \multicolumn{2}{|l|}{$\begin{array}{l}\text { F.L. Meijler, Chairman } \\
\text { A.C. Arntzenius } \\
\text { A.J. Dunning }\end{array}$} & $\begin{array}{l}\text { A.C. van Rossum } \\
\text { F.W.A. Verheugt }\end{array}$ \\
\hline & $\begin{array}{l}\text { A.J. Dunning } \\
\text { P.G. Hugenholtz } \\
\text { G.A. van der Kley } \\
\text { K.I. Lie }\end{array}$ & Academic Medical Center, Amsterdam & $\begin{array}{l}\text { A.J. Dunning, Chief } \\
\text { J.P. van Mantgem } \\
\text { J.D. Durrer }\end{array}$ \\
\hline & $\begin{array}{l}\text { H.R. Michels } \\
\text { J.P. Roos }\end{array}$ & Catharina Hospital, Eindhoven & $\begin{array}{l}\text { H.R. Michels } \\
\text { J.J.R.M. Bonnler }\end{array}$ \\
\hline & $\begin{array}{l}\text { J.Th.Ch. Vonk } \\
\text { H.J.J. Wellens } \\
\text { J.P. Zijlstra }\end{array}$ & Leyenburg Hospital, The Hague & $\begin{array}{l}\text { G.A. van der Kley } \\
\text { F.J. de Nooyer } \\
\text { F. Vermeer }\end{array}$ \\
\hline \multirow[t]{2}{*}{ Policy Advisory Board } & \multirow{2}{*}{$\begin{array}{l}\text { O.S. Miettinen, Chairman } \\
\text { M.E. Bertrand } \\
\text { C.R. Conti } \\
\text { D.G. Julian } \\
\text { E.L. Noach } \\
\text { A. Vedin }\end{array}$} & Sint Lambertus Hospital, Helmond & $\begin{array}{l}\text { J.P. Zijlstra } \\
\text { R.J.A.F. Vroom }\end{array}$ \\
\hline & & University Hospital, Leiden & $\begin{array}{l}\text { B. Buis, Chief } \\
\text { A.C. Arntzenius } \\
\text { J.G. Engbers }\end{array}$ \\
\hline Classification Committee & $\begin{array}{l}\text { J.W. Viersma, Chairman } \\
\text { J.M. de Beyer } \\
\text { P.J. de Feyter }\end{array}$ & & $\begin{array}{l}\text { G.P. Molhoek } \\
\text { C. van Rees }\end{array}$ \\
\hline \multirow[t]{4}{*}{ Coordinating Center } & \multicolumn{2}{|l|}{$\begin{array}{l}\text { J. Lubsen, Director } \\
\text { J.G.P. Tijssen } \\
\text { (chief statistician) }\end{array}$} & $\begin{array}{l}\text { H.J.J. Wellens, Chief } \\
\text { F.W.H.M. Bär } \\
\text { C. de Zwaan } \\
\text { M. Ramentol }\end{array}$ \\
\hline & $\begin{array}{l}\text { G. Bédier de Prairie } \\
\text { M. Bokslag } \\
\text { S. van der Does }\end{array}$ & Radboud Hospital, Nijmegen & $\begin{array}{l}\text { J.Th.Ch. Vonk, Chief } \\
\text { R.Th. van Dam } \\
\text { N.H.J. Pijls }\end{array}$ \\
\hline & $\begin{array}{l}\text { R.T. van Domburg } \\
\text { Y.M. te Giffel }\end{array}$ & $\begin{array}{l}\text { Thoraxcenter, University Hospital } \\
\text { Rotterdam-Dijkzigt }\end{array}$ & $\begin{array}{l}\text { P.G. Hugenholtz, Chief } \\
\text { M.L. Simoons }\end{array}$ \\
\hline & $\begin{array}{l}\text { H.J.J. Kerkkamp } \\
\text { M. Smlts } \\
\text { C.J. Speelman } \\
\text { P. Vrijdag }\end{array}$ & University Hospital, Utrecht & $\begin{array}{l}\text { F.L. Meijler, Chief } \\
\text { E.O. Robles de Medina } \\
\text { P.W. Westerhof } \\
\text { P.J.P. Kuijer }\end{array}$ \\
\hline \multicolumn{2}{|c|}{ Participating Centers were the cardiology departments of these hospitals: } & \multirow[t]{2}{*}{ University Hospital, Groningen } & K.I. Lie, Chief \\
\hline Free University Hospital, Amsterdam & $\begin{array}{l}\text { J.P. Roos, Chief } \\
\text { H.J.J. Kerkkamp }\end{array}$ & & $\begin{array}{l}\text { P.H.J.M. Dunselman } \\
\text { L. van Wijk }\end{array}$ \\
\hline
\end{tabular}

